\title{
Frequencies of UDP-Glucuronosyltransferase 1 (UGT1A1) Gene Promoter Polymorphisms Among Distinct Ethnic Groups From Brazil
}

\author{
K.Y. Fertrin, ${ }^{1}$ M.S. Gonçalves, ${ }^{2}$ S.T.O. Saad, ${ }^{1}$ and F.F. Costa ${ }^{1 *}$ \\ ${ }^{1}$ Hemocentro-UNICAMP, Cidade Universitária “Zeferino Vaz”, Campinas, São Paulo, Brazil \\ ${ }^{2}$ Universidade Federal da Bahia, Salvador, Bahia, Brazil
}

\begin{abstract}
A polymorphism in the promoter region of the UDP-glucuronosyltransferase 1 (UGT1A) gene is associated with Gilbert syndrome (GS), a benign form of mild unconjugated hyperbilirubinemia. We genotyped 157 individuals from Brazil, comprising 71 Caucasians, 54 African-derived subjects, and 32 Parakanã Indians. Frequencies of the alelle (TA) ${ }_{7}$ associated with GS found in this study were $0.324,0.407$, and 0.328 , respectively. The genotype frequencies differed significantly between Caucasians and Africanderived individuals. The high frequencies of $(\mathrm{TA})_{7}$ polymorphism among the three groups confirm previous data that this polymorphism is very ancient and appears to be distributed throughout the world. (c) 2002 Wiley-Liss, Inc.
\end{abstract}

KEY WORDS: Gilbert syndrome; UGT1A; (TA) polymorphism; Amerindians; Parakanã Indians

\section{INTRODUCTION}

Gilbert syndrome (GS) is a benign form of unconjugated hyperbilirubinemia occurring in the absence of structural liver disease and overt hemolysis, characterized by intermittent mild jaundice. The identification of the UDP-glucuronosyltransferase 1 (UGTA1) locus, which encodes for a family of UGTA1 isoforms, sheds light on the mechanism of hereditary transmission of

Grant sponsor: FAPESP (Fundação de Amparo à Pesquisa do Estado de São Paulo); Grant sponsor: CNPq (Conselho Nacional de Desenvolvimento Científico e Pesquisa).

*Correspondence to: F.F. Costa, Hemocentro-UNICAMP, Cidade Universitária "Zeferino Vaz", Caixa Postal 6198, CEP. 13083-970, Campinas, São Paulo, Brazil.

E-mail: ferreira@unicamp.br

Received 15 November 2000; Accepted 26 October 2001 this disorder [Clarke et al., 1997]. The majority of GS cases are associated with a polymorphism in the promoter region of the UGT1A gene, in which a variable number of thymine-adenine (TA) repeats change the length of the TATA element, the binding site for factor IID, which is important in the transcription mechanism [Monaghan et al., 1996]. The presence of seven repeats, instead of the wild-type six repeats, has been found to be associated with reduction in the efficiency of transcription of the UGTA1-gene, and patients with clinically diagnosed GS were homozygous for the (TA $)_{7}$ alelle [Bosma et al., 1995]. In addition, the presence of the $(\mathrm{TA})_{7}$ repeat has been associated with increased bilirubin levels in apparently normal subjects, as well as in homozygotes and heterozygotes for $\beta$ thalassemia [Galanello et al., 1997, 1999], glucose-6phosphate dehydrogenase (G6PD) deficiency [Kaplan et al., 1997], neonatal jaundice [Bancroft et al., 1998], hereditary spherocytosis [Miraglia Del Giudice et al., 1999], and sickle cell anemia [Passon et al., 1998].

Several studies have recently shown differences among the frequencies of the $(\mathrm{TA})_{7}$ polymorphism according to the origin of the population. In a North American population with European Caucasian origin, the (TA) ${ }_{7}$ frequency was 0.387 , while in Asians, it was 0.160. In another group from North and Central America, with different degrees of African descent, besides the higher $(\mathrm{TA})_{7}$ frequency of 0.426 , the presence of $(\mathrm{TA})_{5}(0.035)$ and $(\mathrm{TA})_{8}(0.069)$ alelles were observed [Beutler et al., 1998]. In a study with a population of Japanese neonates [Akaba et al., 1999], the frequency of (TA) $)_{7}$ was as low as 0.070 , while the estimated percentage of subjects homozygous for (TA ${ }_{7}$ was $10-13 \%$ in a Scottish population [Monaghan et al., 1996].

The ethnic origin of the Brazilian population is highly heterogenous. It is comprised of immigrants from Europe, Africa, and Asia, as well as Amerindian groups, which results in a complex race admixture that differs widely from previously studied populations. Thus, an increasing interest in determining for the first time the prevalence of the $(\mathrm{TA})_{7}$ polymorphism in the Brazilian population led us to study a sample of three major ethnic groups that comprise the Brazilian population. 
TABLE I. UGT1A Gene Promoter Genotypes in Three Different Brazilian Populations

\begin{tabular}{lcccccccc}
\hline & \multicolumn{8}{c}{ Genotype } \\
\cline { 2 - 9 } Population & $6 / 6(\mathrm{n})$ & $6 / 7(\mathrm{n})$ & $7 / 7(\mathrm{n})$ & $5 / 6(\mathrm{n})$ & $5 / 8(\mathrm{n})$ & $5 / 7(\mathrm{n})$ & $6 / 8(\mathrm{n})$ & Total (n) \\
\hline Caucasian & 32 & 28 & 9 & 1 & 0 & 0 & 1 & 71 \\
African-derived & 13 & 25 & 9 & 5 & 1 & 1 & 0 & 54 \\
Parakanã Indians & 12 & 19 & 1 & 0 & 0 & 0 & 0 & 32 \\
\hline
\end{tabular}

\section{MATERIALS AND METHODS}

\section{Selection of Groups}

Three major ethnic groups were studied. The first group comprised 71 individuals from Caucasian descendants (students and members of the staff of the University Hospital of Campinas, South-Eastern Brazil), whose ancestors were usually from Italy, Spain, Portugal, and Germany. The second group consisted of 54 African-derived individuals (students and staff of laboratories from the Federal University of Bahia, North-Eastern Brazil, where the majority of the population is of African descent). The third group was composed of 32 samples of Parakanã Indians, an Amazonian Indian polygamous population belonging to the Tupi tribe, where marriage of males to their sister's daughter is favored, resulting in a highly inbred population. Informed consent was obtained from all subjects.

\section{Detection of the (TA) $\mathbf{n}$ Polymorphism}

Genomic DNA was extracted from peripheral blood cells using standard methods. DNA was amplified by polymerase chain reaction (PCR) using primers as described by Monaghan et al. [1996]. The products were run in a $6 \%$ denaturing polyacrilamide gel ( $8.3 \mathrm{M}$ urea) and subsequently stained by silver precipitation [Miraglia del Giudice et al., 1999].

\section{RESULTS}

Table I shows the genotype frequencies in each different group of the population. The homozygous genotype $7 / 7$ frequency was $12.7 \%(9 / 71)$ in the Caucasian population, $16.7 \%(9 / 54)$ in the Africanderived population, and $3.1 \%(1 / 32)$ in the Parakanã Indians. The frequency of homozygotes (7/7) in Amerindians appeared relatively low, although the number of analyzed individuals was too small to draw a definitive conclusion. The distribution of $6 / 6,6 / 7,7 / 7$, and other genotypes differed significantly between the Caucasian and the African-derived population $\left(\chi^{2}=8.82 ; P=0.0318\right)$. The $U G T 1 A 1$ alelle frequencies are summarized in Table II.

\section{DISCUSSION}

As shown in Table II, the estimated gene frequency of $(\mathrm{TA})_{7}$ was 0.324 in the Caucasian population, almost identical to the one found in the Parakanã Indians (0.328), while the same gene had a frequency of 0.407 in the African-derived population.
Our data are in agreement with those reported by Beutler et al. [1998] in the United States, and Iolascon et al. [2000] regarding Caucasian populations in Italy. The presence of the alelles $(\mathrm{TA})_{5}$ and $(\mathrm{TA})_{8}$ in the Brazilian Caucasian population suggests that some subjects may have undergone an African admixture, which is not surprising given the origin of the Brazilian population. However, it is interesting to emphasize that Iolascon et al. [1999] also reported the presence of these alelles among the Caucasian population of Southern Italy.

It is noteworthy that the estimated $(\mathrm{TA})_{7}$ gene frequency among the Parakanã Indians (0.328) was almost the same as found in Caucasians (0.324). Although the number of studied individuals was small, this group is polygamous and favors marriage of males to their sister's daughters, resulting in a population that is very inbred [Black et al., 1981]. The observed frequency is higher than that reported for populations from Asian origin [Akaba et al., 1999]. There is a report of two other groups of Brazilian Indians that showed gene frequencies slightly lower than reported here [Hall et al., 1999]. Since the Amerindian population has a probable Asian origin, a larger number of individuals from different Amerindian groups should be analyzed in order to draw a definitive conclusion regarding this discrepancy.

The presence of only two alleles in the Indian population, while there are at least four in the African population, would indicate that the African population is older than the Indian population, which is in agreement with other reports regarding mitochondrial genome variations in these populations. [Hedges, 2000; Ingman et al., 2000]. The alelle frequency of the African-Brazilians seems to be very similar to that reported by Beutler et al. [1998] in the United States for the African-North Americans.

A great deal of variability is observed at the UGT1A1 promoter among populations from different ethnic backgrounds. The two common alleles, 6 and 7, were found in all populations, but their frequencies vary

TABLE II. Alelle Frequencies of (TA) $)_{\mathrm{n}}$ Polymorphisms in the UGT1A Gene Promoter in Three Brazilian Populations

\begin{tabular}{llcc}
\hline Alelle & Caucasian & African-derived & $\begin{array}{c}\text { Parakanã } \\
\text { Indians }\end{array}$ \\
\hline$(\mathrm{TA})_{5}$ & $0.007(1)$ & $0.065(7)$ & Zero \\
$(\mathrm{TA})_{6}$ & $0.662(94)$ & $0.519(56)$ & $0.672(43)$ \\
$(\mathrm{TA})_{7}$ & $0.324(46)$ & $0.407(44)$ & $0.328(21)$ \\
$(\mathrm{TA})_{8}$ & $0.007(1)$ & $0.009(1)$ & Zero \\
\hline
\end{tabular}

Numbers in parentheses are the number of chromosomes. 
significantly among the ethnic groups. The high frequency of the $(\mathrm{TA})_{7}$ polymorphism may be relevant in countries like Brazil [Sonati et al., 1996], where there is also a high frequency of hemoglobinopathies, because this alelle is strongly associated with hyperbilirubinemia and gallstones in sickle cell anemia and spherocytosis, and could be responsible for the heterogeneity of the clinical presentation of these disorders [Galanello et al., 1997, 1999; Passon et al., 1998; Miraglia del Giudice et al., 1999].

\section{REFERENCES}

Akaba K, Kimura T, Sasaki A, Tanabe S, Wakabayashi T, Hiroi M, Yasumura S, Maki K, Aikawa S, Hayasaka K. 1999. Neonatal hyperbilirubinemia and a common mutation of the bilirubin uridine diphosphate-glucuronosiltransferase gene in Japanese. J Hum Genet $44: 22-25$.

Bancroft JD, Kreamer B, Gourley GR. 1998. Gilbert syndrome accelerates development of neonatal jaundice. J Pediatrics 132:656-660.

Beutler E, Gelbart T, Demina A. 1998. Racial variability in the UDP. glucoronosiltransferase 1 (UGT1A1) promoter: a balanced polymorphism for regulation of bilirubin metabolism? Proc Natl Acad Sci USA 95:8170-8174.

Black FL, Salzano FM, Layrisse Z, Franco MHLP, Harris NS, Weimer TA. 1981. Restriction and persistence of polymorphisms of HLA and other blood genetic traits in the Parakanã Indians of Brazil. Am J Phys Anthropol 52:119-132.

Bosma PJ, Chowdury JR, Bakker C, Gantla S, de Boer A, Oostra BA, Lindhout D, Tytgat GNJ, Jansen PLM, Oude Elferink RPJ, Chowdury NR. 1995. The genetic basis of the reduced expression of bilirubin UDPglucoronosiltransferase 1 in Gilbert's syndrome. N Eng J Med 333:1171-1175.

Clarke DJ, Moghrabi N, Monaghan G, Cassidy A, Boxer M, Hume R, Burchell B. 1997. Genetic defects of the UDP-glucuronosyltransferase1 (UGT1) gene that cause familial non-haemolytic unconjugated hyperbilirubinaemias. Clin Chim Acta 266:63-74.
Galanello R, Perseu L, Melis MA, Cipollina L, Barella S, Giagu N, Turco MP, Maccioni O, Cao A. 1997. Hyperbilirubinaemia in heterozygous beta-thalassaemia is related to co-inherited Gilbert's syndrome. Br J Haematol 99:433-436.

Galanello R, Cipollina L, Dessi C, Giagu N, Lai E, Cao A. 1999. Co-inherited Gilbert's syndrome: a factor determining hyperbilirubinemia in homozygous $\beta$-thalassemia. Haematologica 84:103-105.

Hall D, Ybazeta G, Destro-Bisol G, Petzl-Erler ML, Di Rienzo A. 1999 Variability at the uridine diphosphate glucoronosyltransferase 1A promoter in human populations and primates. Pharmacogenetics 5:591-599.

Hedges SB. 2000. A start for population genomics. Nature 408:652-653.

Ingman M, Kaessmann H, Pääbo S, Gyllensten U. 2000. Mitochondrial genome variation and the origin of modern humans. Nature 408:708713.

Iolascon A, Faienza MF, Centra M, Storelli S, Zelane L, Savoia A. 1999 (TA $)_{8}$ allele in the UGTIAI gene promoter of a Caucasian with Gilbert's syndrome. Haematologica 84:106-109.

Iolascon A, Perrota S, Coppola B, Carbone R, Ciudice EM. 2000. Frequency of Gilbert's syndrome associated with UGTAI (TA) ${ }_{7}$ polymorphism in Southern Italy. Haematologica 85:335-336.

Kaplan M, Renbaum P, Levy-Lahad E, Hammerman C, Lahad A, Beutler E. 1997. Gilbert syndrome and glucose-6-phosphate dehydrogenase deficiency: a dose-dependent genetic interaction crucial to neonatal hyperbilirubinemia. Proc Natl Acad Sci USA 94:12128-12132.

Miraglia del Giudice E, Perrotta S, Nobili B, d’Urzo G, Conte ML, Cutillo S, Iolascon A. 1999. Co-inheritance of Gilbert's syndrome increases the risk for developing gallstones in patients with hereditary spherocytosis (HS). Blood 92:2259-2262.

Monaghan G, Ryan M, Seddon R, Hume R, Burchell B. 1996. Genetic variation in bilirubin UDP-glucoronosyltranferase gene promoter and Gilbert's syndrome. Lancet 347:578-581.

Passon RG, Howard TA, Zimmerman SA, Schultz WH, Ware RE. 1998. The effect of UDP-glucuronosyltransferase 1A (UGT1A) promoter polymorphisms on serum bilirubin levels and cholelithiasis in patients with sickle cell anemia. Blood 92(Suppl 1):645a.

Sonati MF, Kimura EM, Grotto HZW, Gervasio AS, Costa FF. 1996 Hereditary hemoglobinopathies in a population from Southeast Brazil Hemoglobin 20:175-179. 